\title{
ON AN ANGIENT EGYPTIAN METHOD OF DIAGNOSING PREGNANGY AND DETERMINING FOETAL SEX
}

\author{
by
}

P. GHALiOUNGUi, SH. KHALIL, and A. R. AMMAR

THE recognition of pregnancy must have always exerted the acumen of physicians, not only on medical grounds, but for a host of social, legal, and political motives. These motives were certainly of paramount importance in such a highly organized society as Pharaonic Egypt, where wedding contracts with previously married women testify to that interest ${ }^{1}$ (Jonckheere, I954). Moreover, in feudal or monarchical societies where fierce struggles could at any time arise over royal successions, the political necessity of securing a male heir must have been a constant cause of concern among the ruling classes.

Ever since the diagnosis of pregnancy by biological tests was put on scientific bases by Aschheim and Zondek ${ }^{2}$ in 1929, interest has reawakened in some diagnostic methods described in the Kahoun medical papyrus, ${ }^{3}$ the Berlin papyrus no. 3038,4 and the Carlsberg papyrus. ${ }^{5}$ These manuscripts were written about three thousand years ago, but they are only copies from originals, probably about fifteen hundred years older. The methods therein described were copied by the Greeks, some by no less an authority than Hippocrates ('Aphorisms', and 'On Sterile Women'), and handed over by them to the Arabs, and through these to medieval Europe. The routes which these survivals followed were studied by Iversen, ${ }^{5}$ Dawson, ${ }^{6}$ and Ebers. ${ }^{7}$ According to Kazancigil $^{8}$, they are still being practised today in some parts of Asia Minor.

The principles on which these tests are built vary, but those that have recently attracted attention, owing to the possibility of their having originated from accurate scientific observation, claim that by watering different cereals with the urine of pregnant women, the kind of cereal that grows best indicates the sex of the expected child, while if none grows, the women must be judged nonpregnant or sterile. (Berlin Papyrus, vs., 2, 2-5 and Carlsberg Papyrus, III, $\mathrm{I}, 6-\mathrm{x}+3$.

This is the actual text of the Berlin Papyrus as translated into English by Dawson: ${ }^{6}$

Another test for a woman who will bear or a woman who will not bear. Wheat and spelt: let the woman water them daily with her urine like dates and like sh'at seeds in two bags. If they both grow, she will bear: if the wheat grows, it will be a boy; if the spelt grows, it will be a girl. If neither grows, she will not bear.

There does not seem to be a general agreement among egyptologists, however, on the rendering of the Egyptian names of the cereals. Whereas Wreszinski' and Dawson ${ }^{6}$ translate them by wheat (Weize) for boys, and spelt for girls, Iversen ${ }^{5}$ gives wheat and barley respectively, and Grapow ${ }^{9}$ translates them by 'Gerste', barley, for boys, and 'Emmer', buckwheat, for girls. The last 


\section{P. Ghalioungui, Sh. Khalil, A. R. Ammar}

author, commenting on the text, and on the version found in a German book of popular medicine of the Middle Ages, points out that the specificity of the cereals in regard to foetal sex is reversed in the latter. He adds that, as a philologist, he cannot discuss whether the Ancient Egyptians had a notion of the pregnancy hormones and of the Aschheim-Zondek test, but he can only state that in Egypt barley was associated with a boy, and wheat with a girl, because in Egyptian barley was masculine, and wheat was feminine. In German, the genders are reversed: Gerste, barley, is feminine and corresponds in the test to a girl, and Weizen, wheat, is masculine and corresponds to a boy. According to him, the association stemmed from purely verbal considerations.

In medieval Arabic works on medicine, we find a variant of the test in a well-known book of the tenth century, Kamel-el-Sinaa fil Tibb (Chapter vir), written by Aly Abul Abbas el Magousy, the Haly Abbas of medieval European writers. It is described thus: '.. . and of these tests, it has been said that if seven grains of wheat, seven of barley, and seven of beans are placed in different vessels, and if one (of the sterile couple) urinates upon them, if after seven days the grains grow, then sterility is not on his (or her) part'. The test, on which Al-Magousy carefully avoids making any comment, mentions nothing of the sex of the foetus; it repeatedly utilizes the number seven, and seems to implicate the presence in the urine of fertile persons of either sex of a vital factor capable of inducing growth in grains, as it is of causing the growth of progeny. It is remarkable that in contradistinction to the Arab version, sterility on the part of the male partner is not mentioned in any known Egyptian or Greek text.

Various modern workers have tried the test to decide on its reliability. One of the difficulties they met was the toxicity of urine, and in order to overcome it, they either dialysed or diluted it. Manger ${ }^{10}$, using filter paper beds under continuous aeration to eliminate the retarding effect of ammonia formed from urea, and diluting the urine up to a hundred times, found no difference between pregnant and non-pregnant urines. He did find, however, that when barley grew quicker, a girl was born, while if wheat grew faster, the child was a boy. When the diagnosis was uncertain the foetus was a boy. In that way, a correct prediction was made in eighty per cent of the cases.

Using mixed pregnancy urine, Hoffman ${ }^{11}$ found that non-pregnant urine prevented the growth of various kinds of barley and wheat, while pregnant urine permitted growth, albeit at a slower rate than water-treated controls. After a month, however, seeds watered with pregnancy urine showed stronger growth and vitality than controls. Hoffman made no attempt at sex diagnosis, but he found that neither dialysis, nor boiling of the urine, produced any difference in the results. He concluded that the gonadotrophic hormones which are responsible for the Aschheim-Zondek test are not the cause of the difference between pregnant and non-pregnant urine.

\section{Methods and Material}

Forty-eight samples of urine were sent with a serial number from the Department of Gynæcology and Obstetrics of Ain Shams University Hospital to the Department of Plant Physiology of the National Research Centre. Two 
On an Ancient Egyptian Method of Diagnosing Pregnancy and Determining Foetal Sex came from male individuals; 6 from non-pregnant females, and 40 from pregnant females.

Seeds of 4 different kinds, 2 varieties of wheat (baladi and hindi) and 2 of barley (baladi and hindi), were placed on filter paper in Petri dishes, 50 seeds per bed. In each test, 12 beds were used: 6 of barley and 6 of wheat. Of each 6 , 2 were watered with undiluted urine, 2 with urine diluted I/I with distilled water, and 2 with distilled water (see diagram).

Each urine: 12 dishes

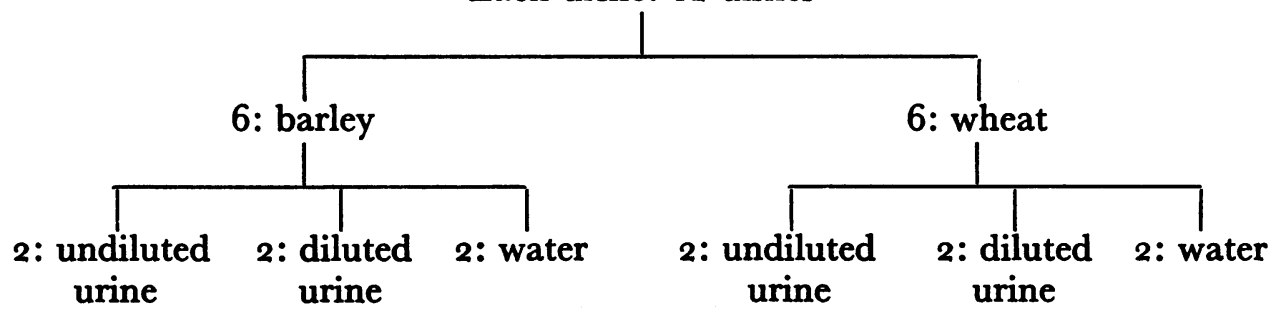

The Petri dishes were kept under constant temperature $\left(25^{\circ} \mathrm{C}_{\left. \pm \mathrm{I}^{\circ}\right)}\right)$ for three to five days, after which the number of germinated seeds was counted. This gave a 'germination percentage'. Ten representative seeds were then photographed to record the stage of germination. This was recorded thus: $\dagger$, roots just protruded; $\uparrow \dagger$, from 0.1 to $0.5 \mathrm{~cm}$.; and $\dagger \dagger \dagger$, more than $0.5 \mathrm{~cm}$.

At the end of gestation, the results were compared with the records of the owners of the urines (Table I).

Results and Discussion

The test clearly consists of two different tests combined together. One concerns the diagnosis of pregnancy (or of fertility): if no cereal grows, the woman is not pregnant (or is sterile). The other concerns the sex of the expected child and depends on which of the two cereals grows faster.

That the two parts should be considered separately is suggested by the fact that no other test described in the papyri mentions anything about sex prediction. Neither does the Arab version. In fact, the latter applies the test to both men and women. This view is further supported by the varying results obtained for each of the two parts of the test by the various workers who experimented with them.

Results (Table I):

A. The test for pregnancy

(a) Non-pregnant urine from 8 cases, 2 males and 6 females. In none did any growth occur $(3 e, 3 f, 5 j)$.

(b) Non-pregnant urine from 20 cases, to males and io females. Seeds planted in soil: No growth.

(c) Pregnancy urine, 40 cases.

No growth (Fig. I):

Poor growth:

12 cases (4g and $4 \mathrm{~h})$.

Growth approximating controls: 23 cases (I and 2). 


\section{P. Ghalioungui, Sh. Khalil, A. R. Ammar}

In no case did growth equal in degree that of seeds watered with distilled water. In that respect our results agree with those of Hoffman. ${ }^{11}$ They vary from those of Manger, ${ }^{10}$ who found no difference between pregnant and non-pregnant urine, possibly because he used much more dilute urine, and aerated his seeds. We tried the effect of aeration (Table II) and we found that this procedure accelerated the growth of seeds watered with urine but had no effect on watertreated ones (Fig. 2). Apparently, the inhibiting pregnancy factor can be eliminated by aeration or oxidation.

One possibly significant difference between our method and the Ancient Egyptians' is that we kept the seeds in a Petri dish on filter paper, while the papyri recommend mixing with dates (?) or earth (?). To exclude the possibility that earth favours the growth of seeds by adsorbing some toxic factor, we tried the urine of 10 males and Io non-pregnant females on wheat and barley grown in pots containing arable soil. No growth was obtained in any of these.

It seems justifiable to conclude that when barley and wheat are watered with urine, if any or both kinds of grain grow, then the urine comes from a pregnant woman. The reverse is not true: absence of growth does not eliminate pregnancy. In other words, normal urine arrests the germination of both wheat and barley. In the urine of some pregnant women, the inhibiting factor ceases to appear or is inhibited by a pregnancy factor. The neutralization is not constant, for it was absent in 12 out of the 40 cases, and was only reduced in another 5 .

The nature of the interfering substance in urine is not yet clear. In Hoffmann's experiments, it could not be eliminated by boiling or by dialysis. It is, therefore, neither a gonadotrophin or other protein substance, nor an electrolyte.

\section{B. Prediction of the sex}

In the previously mentioned results concerning the diagnosis of pregnancy, inhibition of growth was taken to include both wheat and barley. Selective inhibition of one kind was observed in 23 cases. In 7 , the selectivity was complete, no growth at all occurring in the other cereal. In these, the prediction of the sex was correct. In the remaining 16 , growth equal to that obtained with nonpregnant urine occurred in the other cereal. In these, prediction was wrong. In 5 cases, growth occurred to a practically equal degree in both kinds. This equivocal result was only observed in mothers of girls, a fact that does not agree with the conclusions of Manger, ${ }^{10}$ who found uncertain results in the case of mothers of boys.

Even if we add to the 7 cases in which diagnosis was correct, the 12 cases in which growth, though selective, was very poor, but in which the results agreed with the expectations of the test, the total of positive cases is only 19 out of 40. This clearly indicates the unreliability of the test, since the chances of correct prediction are I to 2. The figures in these added 12 cases do not exceed, however, those obtained with non-pregnant female or even with male urine, so that even this corrective addition is not justified.

A final judgement cannot be pronounced, however, without considering two possible errors in the test as carried out.

In the first place, we have kept the seeds on filter paper while the Egyptians 
On an Ancient Egyptian Method of Diagnosing Pregnancy and Determining Foetal Sex

planted them in a mixture of sand and dates (?). It is possible that the sand by adsorbing some toxic factor favours the growth of seeds. We cannot see, however, how this could favour the growth of barley and not of wheat in some cases, and act in the opposite direction in others. In the second place, there remains the possibility that the seeds mentioned by the papyri are not wheat and barley. Philologists do not seem to agree on that point, but we are not qualified to take part in that discussion.

Finally, no difference was noted between the two varieties of either wheat or barley that we used.

Summary

(I) Urine from pregnant females, non-pregnant females, and normal males was added to seeds of two varieties each of barley and of wheat, using distilled water as a control.

(2) No growth occurred with urine obtained from non-pregnant females, or from males.

(3) The inhibitory effect of urine was diminished by aeration.

(4) Urine from pregnant women inhibited growth in only 12 cases out of 40. In the remaining, appreciable growth occurred.

(5) It is concluded that when growth occurs, the urine is presumably that of a pregnant woman, but the reverse is not necessarily true.

(6) The sex of the unborn child cannot be predicted from the kind of cereal that grows faster.

TABLE I

Germination percentage and rate of germination of wheat and barley, as indicators of pregnancy and sex of unborn children.

\begin{tabular}{|c|c|c|c|c|c|c|c|c|c|c|c|}
\hline \multirow{3}{*}{\multicolumn{2}{|c|}{$\begin{array}{l}\text { No. of } \\
\text { samples } \\
\text { tested }\end{array}$}} & \multicolumn{4}{|c|}{ Urine treatment } & \multicolumn{4}{|c|}{ Water treatment } & \multirow{4}{*}{$\begin{array}{l}\text { Expectation } \\
\text { according } \\
\text { to the } \\
\text { test }\end{array}$} & \multirow{4}{*}{$\begin{array}{l}\begin{array}{c}\text { Actual } \\
\text { result }\end{array} \\
\begin{array}{l}\text { girl } \\
\text { boy }\end{array}\end{array}$} \\
\hline & & \multicolumn{2}{|c|}{ Barley } & \multicolumn{2}{|c|}{ Wheat } & \multicolumn{2}{|c|}{ Barley } & \multicolumn{2}{|c|}{ Wheat } & & \\
\hline & & \multirow{2}{*}{$\begin{array}{c}\text { Ger. } \\
\% \\
\mathbf{8 4} \\
\end{array}$} & \multirow{2}{*}{$\begin{array}{c}\begin{array}{c}\text { Rate of } \\
\text { ger. }\end{array} \\
+\dagger \dagger\end{array}$} & \multirow{2}{*}{$\begin{array}{c}\text { Ger. } \\
\% \\
\overline{78}\end{array}$} & \multirow{2}{*}{$\begin{array}{c}\begin{array}{c}\text { Rate of } \\
\text { ger. }\end{array} \\
\overline{t \dagger}\end{array}$} & \multirow{2}{*}{$\begin{array}{c}\begin{array}{c}\text { Ger. } \\
\%\end{array} \\
90 \\
81\end{array}$} & \multirow{2}{*}{$\begin{array}{c}\begin{array}{c}\text { Rate of } \\
\text { ger. }\end{array} \\
t+t \\
t+t\end{array}$} & \multirow{2}{*}{\begin{tabular}{|c|}
$\begin{array}{c}\text { Ger. } \\
\%\end{array}$ \\
76 \\
79 \\
\end{tabular}} & \multirow{2}{*}{$\begin{array}{c}\begin{array}{c}\text { Rate of } \\
\text { ger. }\end{array} \\
+t \dagger \\
+\dagger\end{array}$} & & \\
\hline $\mathbf{r}$ a & $\begin{array}{l}3 \\
4\end{array}$ & & & & & & & & & & \\
\hline $\begin{array}{r}2 \mathrm{c} \\
\mathrm{d}\end{array}$ & $\begin{array}{r}10 \\
6\end{array}$ & $\begin{array}{r}67 \\
3\end{array}$ & tt & $\begin{array}{l}13 \\
59 \\
\end{array}$ & $t$ & $\begin{array}{l}75 \\
87\end{array}$ & $t+t$ & $\begin{array}{l}80 \\
69\end{array}$ & tt† & $\begin{array}{l}\text { girl } \\
\text { boy }\end{array}$ & $\begin{array}{l}\text { boy } \\
\text { girl }\end{array}$ \\
\hline $\begin{array}{l}3 \mathrm{f} \\
\mathrm{f}\end{array}$ & $\begin{array}{l}\text { I } \\
\text { I }\end{array}$ & $\overline{8}$ & - & $\underline{4}$ & - & $\begin{array}{l}73 \\
84\end{array}$ & tt & $\begin{array}{l}88 \\
71\end{array}$ & ttt & $\begin{array}{l}\text { non-preg. } \\
\text { non-preg. }\end{array}$ & $\begin{array}{l}\text { Male subject } \\
\text { Male subject }\end{array}$ \\
\hline $\begin{array}{r}4 g \\
h\end{array}$ & $\begin{array}{l}5 \\
7\end{array}$ & $\overline{16}$ & - & $\frac{6}{-}$ & - & $\begin{array}{l}90 \\
86\end{array}$ & $t+t$ & $\begin{array}{l}93 \\
83\end{array}$ & tt & $\begin{array}{l}\text { non-preg. } \\
\text { non-preg. }\end{array}$ & $\begin{array}{l}\text { boy } \\
\text { girl }\end{array}$ \\
\hline $5 \underset{j}{\mathbf{j}}$ & $\begin{array}{l}5 \\
6\end{array}$ & $4_{6}^{1}$ & $\stackrel{t+}{\dagger}$ & 33 & $t$ & $\begin{array}{l}70 \\
63\end{array}$ & ttt & $\begin{array}{l}64 \\
75\end{array}$ & $t+t$ & ? & $\begin{array}{l}\text { girl } \\
\text { non-preg. }\end{array}$ \\
\hline
\end{tabular}

$\dagger$ roots just protruded $\quad \dagger$ roots from 0.1 to $0.5 \mathrm{~cm}$. $\dagger \dagger \dagger$ roots more than $0.5 \mathrm{~cm}$. 


\section{P. Ghalioungui, Sh. Khalil, A. R. Ammar}

TABLE II

Germination percentage and rate of germination of wheat as influenced by aeration.

\begin{tabular}{l|c|c|c|c}
\hline \multirow{2}{*}{ Treatment } & \multicolumn{2}{|c|}{ Aerated } & \multicolumn{2}{c}{ Non-aerated } \\
\cline { 2 - 5 } & $\begin{array}{c}\text { Germination } \\
\%\end{array}$ & $\begin{array}{c}\text { Rate of } \\
\text { germination }\end{array}$ & $\begin{array}{c}\text { Germination } \\
\%\end{array}$ & $\begin{array}{c}\text { Rate of } \\
\text { germination }\end{array}$ \\
\hline Urine & 68 & $\dagger \dagger$ & 10 & $\dagger$ \\
\hline Water & 92 & $\dagger \dagger \dagger$ & 86 & $\dagger \dagger \dagger$ \\
\hline
\end{tabular}

\section{REFERENCES}

I. Jonckhezre, F., Documents Egyptiens sur la durée de la gestation, XIV Congr. int. d'Hist. Méd., Rome, 1954, vol. II, p. 846.

2. ZoNDEK, B., Hypophysenvorderlappen und Schwangerschaft, Endokrinologie, $1929,5,425$.

3. Griffith, F. L., Hieratic Papyri from Kahun and Gurob, London, I898.

4. Wreszinski, W., Der grosse medizinische Papyrus des Berlins Museums, Leipzig, J. C. Heinrich, rgog.

5. I versen, E., Papyrus Carlsberg VIII, Copenhagen, Munksgaard, 1939.

6. Dawson, W. R., Magician and Leech, London, Methuen, p. I43.

7. Ebers, G., Wie Altaegyptisches in die europaeische Volksmedicin gelangte, Ägyptische Sprache und Altertumskunde, 1895, 33, I.

8. Kazancigil, T. R., Sur les traces d'Hippocrate en Anatolie, XVIIe Congr. int. Hist. Méd., Athens, 1960, vol. 1, p. 79.

9. Grapow, H., Grundriss der Medizin der Alten Ägypter, Berlin, Akademie Verlag, 1956, vol. III, p. 67 .

Io. MANGer, J., Untersuchungen zum Problem der Geschlectsdiagnose aus Schwangerenharn, Dtsch. med. Wschr., 1933, 59, 885.

II. Hofrman, W., Versuche zur Schwangerschaftsdiagnose aus dem Harn, Dtsch. med. Wschr., 1934, 60, 822. 


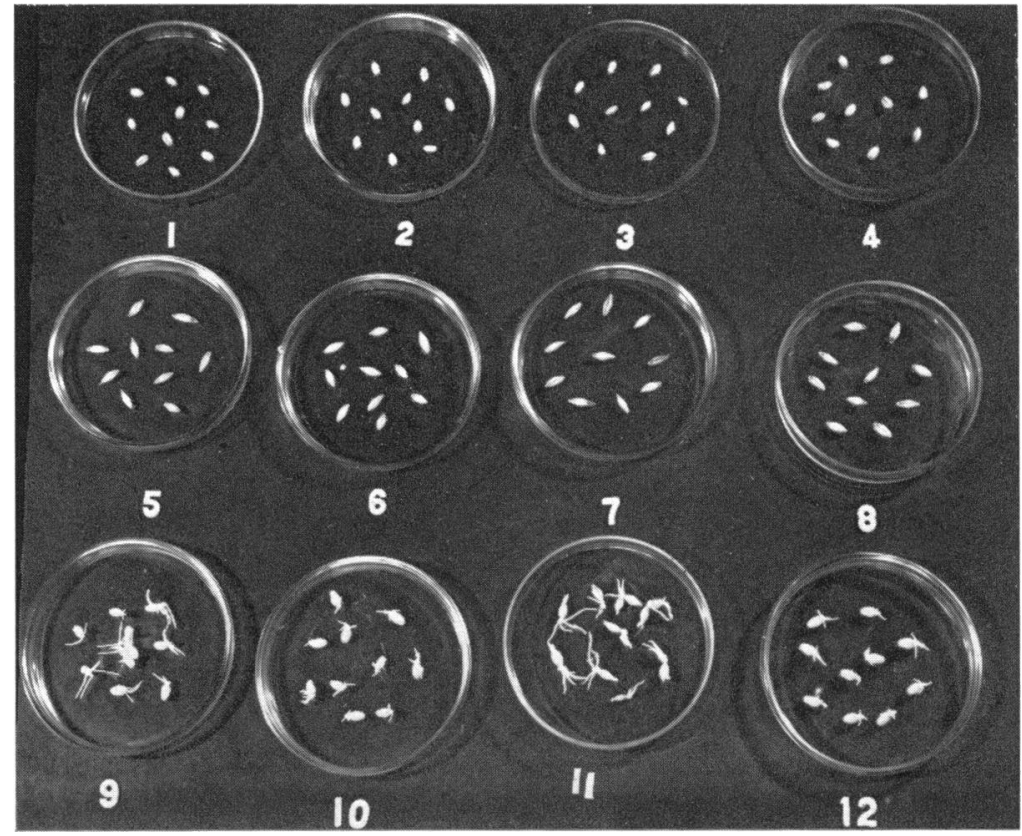

Fig. I

I to 4: ungerminated wheat in urine; 5 to 8: ungerminated barley in urine; 9 to 12 : germinated seeds in water. This urine came from a pregnant lady. The result is negative

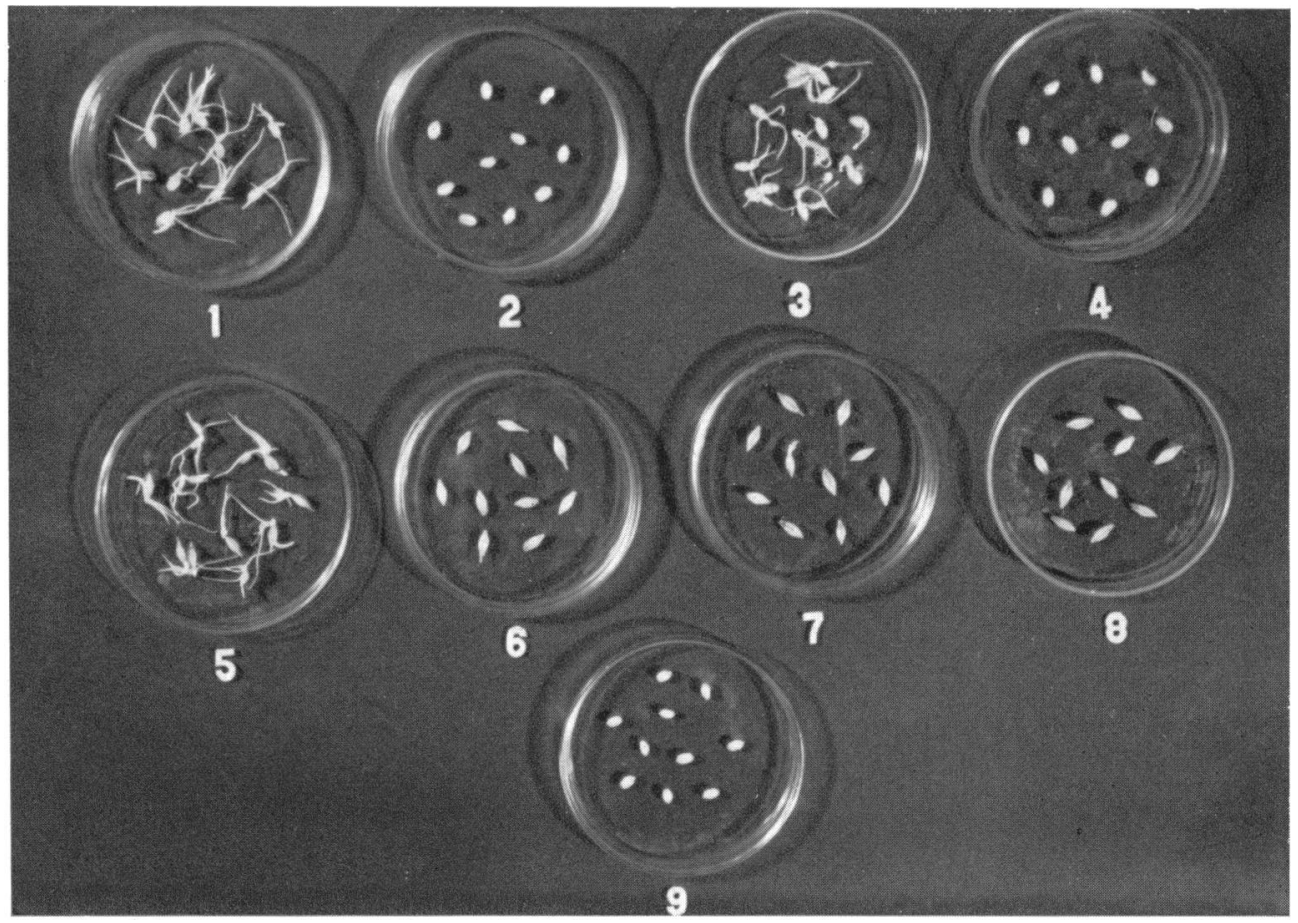

Fig. 2

(1) Baladi wheat, aerated; (2) Baladi wheat, unaerated; (3) Hindi wheat, aerated;

(4) Hindi wheat, unaerated; (5) Baladi barley, aerated;(6) Baladi barley, unaerated;

(7) Hindi barley, aerated; (8) Hindi barley, unaerated; (9) Control: untreated wheat seeds 


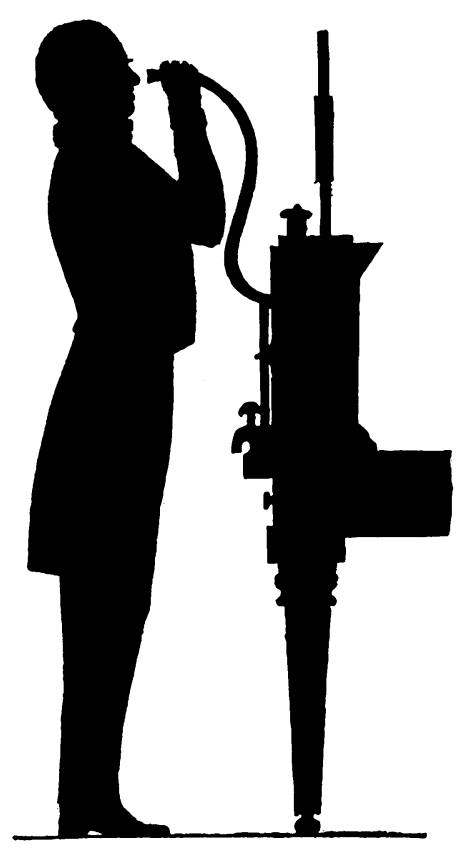

Fig. I. To measure the vital capacity of the lungs

Position of the body in filling the chest before breathing into the Spirometer

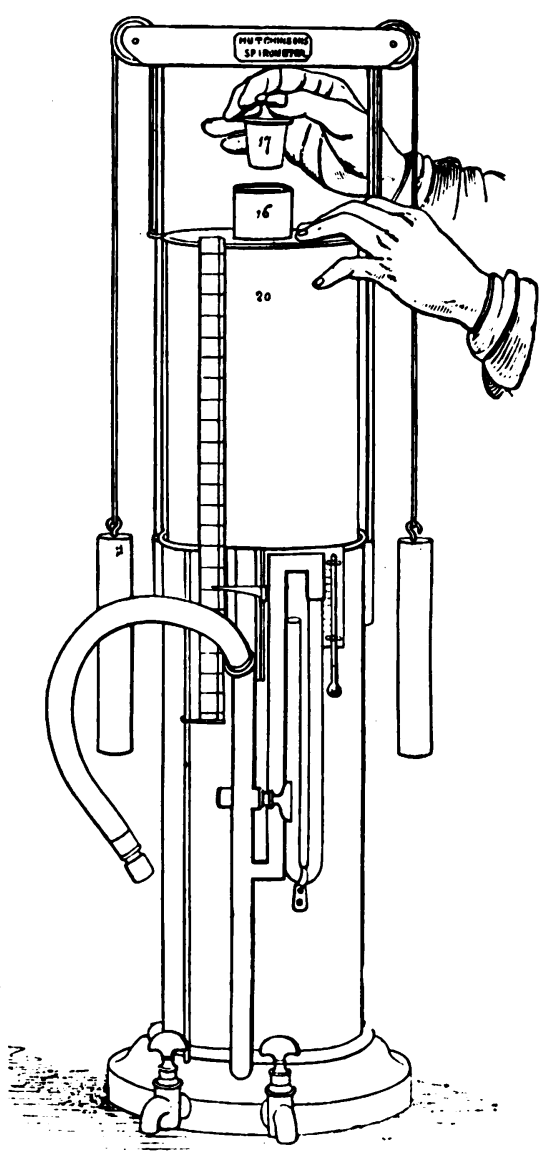

Fig. 2. The Spirometer

Fig. 3

The division of the thoracic movements

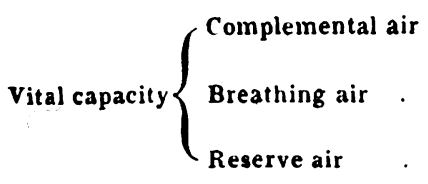

Residual air

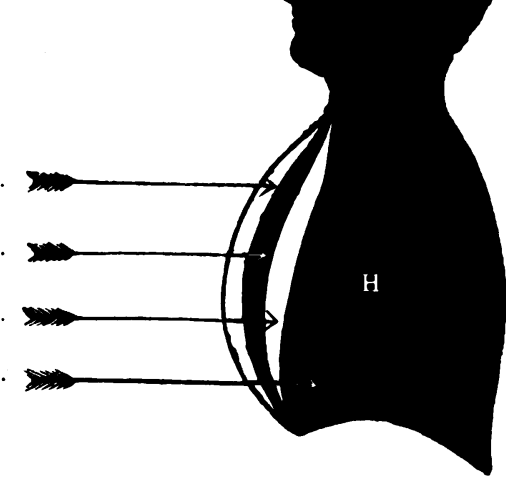

